\title{
Smart Tracking Design in Finding Solar Power Plants
}

\author{
Suwarno $^{1}$, Rohana ${ }^{2}$, Darma Yulianti Purba ${ }^{3}$ \\ 1,2,3 Universitas Muhammadiyah Sumatera Utara, Indonesia \\ yuliantipurba@yahoo.com
}

\section{Abstract}

We know that solar heat can be used as one of the natural resources that are still very abundant on earth and can be used as a new source of energy or better known as solar cells and power plants that use solar cells are generally still static. Therefore we need a mechanical system that can move the position of the solar panel so that it can move according to the position expected by the use of solar panels to get energy from the sun. Arduino Uno serves as the control center of all systems built and tools. in moving the solar panel using Askremote control to give orders to the L298 module as a controller of the dc motor so that the dc motor can move according to the design and construction of the system embedded into the Arduino and the Photo Interrupter functions as a barrier to the movement of the dc motor.

\section{Keywords}

arduino uno; remote control; DC motor; photo interrupter

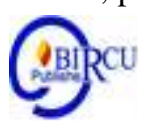

\section{Introduction}

As we know solar energy can be used as a source of electrical energy by using solar cells. We know that solar heat can be used as one of the natural resources that are still very abundant on earth and can be used as a new energy source or better known as Solar Cells. Power plants using solar cells are generally still static. Based on the above, a mechanical system is needed that can move the position of the solar panel so that it can move according to the position expected by the solar cell user.

This system is named the power plant tracking system, where the position of the solar cell panel can be moved by the user according to the sun's position using Remote Control. Utilization of solar radiation can be maximized using the Remote Control system according to the direction or position where the sun is located. So it is hoped that this system can be used to follow the movement of the sun and produce more optimal energy values. Based on the above problems, the authors want to create a system that is useful in the hope of optimizing the working system of solar panels. In accordance with the topic described above.

From the problems that have been described above, the authors conclude that the formulation of the problem is how to design and create a remote control-based power plant tracking system that can produce more optimal energy values.

The purpose of the research in this final report is to make it easier for users of solar power plants to adjust the position of the solar cell to get optimal sunlight by using a remote control-based solar power plant tracking system that has been designed and built by the author and the author can also understand the performance of the system used. will be built and designed.

Law as a social technology in the sense of law as a tool to change society that might be used as an agent of change (Hartanto, 2020). The rapid growth of technology has now enabled the internet to become one of the rapidly evolving advances in information technology (Gunawan and Sulaeman, 2020). With the rapid development of technology, 
especially in the solar power plant which has become a source of energy. So the author is motivated in designing and building a remote control-based solar power generation system that can remotely adjust the position of the solar cell to get optimal sunlight and maximum energy sources.

\section{Review of Literature}

\subsection{Mean of Solar Cell}

Solar cells are a collection of photovoltaic cells that can convert sunlight into electrical energy. In simple cell Solar panels consist of a p- and n-type semiconductor material junction ( $\mathrm{p}-\mathrm{n}$ junction semiconductor) which, when exposed to sunlight, will flow electrons, this flow of electrons is referred to as the flow of electric current. The process of converting electrical energy can be seen in the image below:

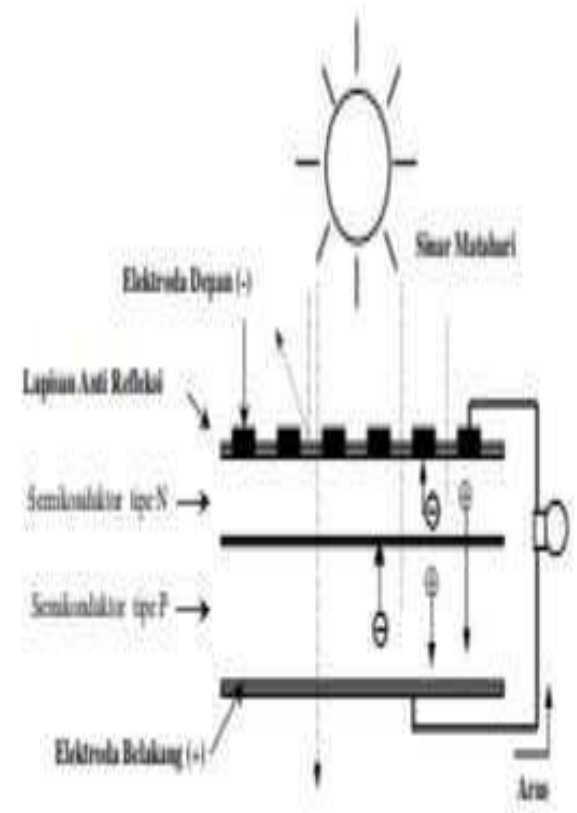

Figure 1. The process of converting solar energy into electrical energy p da solar cell

\subsection{Solar Panel Structure}

The structure of solar cells, namely solar cells based on silicon material and how the first generation (silicon solar cells) and second (thin film) solar cells work.

a. Substrate / Metal backing

The substrate material must also have good electrical conductivity because it also functions as a positive terminal contact for solar cells, so metal or metal materials such as aluminum or molybdenum are generally used.

b. Semiconductor materials

A semiconductor material is the core part of solar cells which usually has a thickness of up to several hundred micrometers for first-generation solar cells (silicon), and 1-3 micrometers for thin-layer solar cells. For the case of the picture above, the semiconductor used is silicon material, which is commonly applied in the electronics industry. As for thin-layer solar cells, semiconductor materials are commonly used and have entered the market. 


\section{c. Metal contacts}

In addition to the substrate as a positive contact, on top of some semiconductor materials, metal or transparent conductive material is usually coated as a negative contact.

d. Anti-reflective coating

The reflection of light must be minimized to optimize the light absorbed by the semiconductor. Therefore, solar cells are usually coated with an anti-reflection layer. This anti-reflection material is a thin layer of material with a large optical refractive index between the semiconductor and air which causes light to be bent towards the semiconductor to minimize the reflected light back.

Solar panels consist of several generations, namely:

1. Wafer-based solar cells

The first generation of photovoltaic cells consisted of a large area, single crystalline layer, single at the PN junction, capable of generating usable electrical energy from a light source with the wavelength of sunlight. These cells are usually made using a diffusion process with silicon wafers. This first-generation solar cell is the dominant technology-based solar cell in the industry commercial production of solar cells, accounting for more than $85 \%$ of the terrestrial solar cell market.

2. Thin film-based solar cells

These cells are based on the use of thin epitaxy(epitaxy refers to a method of depositing monocrystalline films on monocrystalline substrates) to deposit semiconductors on lattice-shake wafers. An advantage of thin-film technology is reduced mass which allows panels to fit on light or flexible materials, even on textiles. Second-generation solar cells now comprise a small segment of the terrestrial photovoltaic market and approximately $90 \%$ of the space market.

\subsection{Arduino Uno Programming Language}

Arduino Uno uses a programming language with the $\mathrm{C}$ language, the Arduino Uno $\mathrm{C}$ programming language is modified and simplified from the Arduino Uno programming language.C. The reason why Arduino uses the basic $\mathrm{C}$ programming language is because the $\mathrm{C}$ language is a language that is very commonly used since the beginning of the computer being created and plays a very important role in software development.

The $\mathrm{C}$ language has created various operating systems and compilers for many programming languages, such as the Linux operating system and many others. $\mathrm{C}$ language is a very powerful language whose strength is close to that of assembly language which produces object code files that very small and executed very quickly so it is often used in operating systems and microcontroller programming. $\mathrm{C}$ language is a multi-flatfoam language because the language can be applied to Windows, Unix and Linux environments, or other operating systems without changing the source code.

The following is a brief explanation of the Arduino $\mathrm{C}$ language characters and Software Arduino:

\section{a. Structure}

Each Arduino program has 2 (two) functions that must exist, the following are 2 structural functions:

1. Void Setup () \{\}

All the code inside the curly braces will be executed only once when the Arduino program is run for the first time. 
2. Void Loop () \{\}

This function will be executed after setup (void setup function) is complete. After running once this function will be executed again, and again continuously until the power supply (power) is removed.

\section{b. Syntax}

Syntax is an element of the $\mathrm{C}$ language for writing formats, here is an explanation:

1. // (one line comment)

Sometimes it is necessary to note to yourself what the code means. Just write two slashes and whatever you type behind will be ignored by the program.

2. $/ * * /($ multiline comment)

If you have a lot of notes, then they can be written on several lines as comments. Anything that lies between these two symbols will be ignored by the program.

3. \{\} (Curly brackets)

Used to define when a program block starts and ends (used also in functions and loops).

Usage example:

Void loop () \{Serial.prinln(val)\}

4. ; (Semicolon)

Each line of code must end with a semicolon (if any semicolon is missing, the program will not run).

Example of use: Delay (100)

\subsection{Variable}

A program can be broadly defined as an instruction to move numbers in an intelligent way. This variable is used to move it.

a. Int (integer)

Used to store numbers in 2 bytes (16 bits). It has no decimal places and stores values from -32.768 and 32.767 .

b. Long

Used when integers are not enough anymore. It uses 4 bytes (32 bits) of memory (RAM) and has a range of 2,147,483,648 and 2,147,483,647.

c. Boolean

A simple variable used to store the value TRUE(true) or FALSE(false). Very useful because it only uses 1 bit of RAM.

d. Float

Used for floating point decimal numbers. It takes up 4 bytes (32 bits) of RAM and has a range of $3.4028235 \mathrm{E}+38$.

e. Char (character)

Stores 1 character using ASCII code (eg 'A' = 65). Uses only 1 byte (8bit) of RAM.

f. Bytes

Numbers between 0 and 255 are the same as char but bytes only use 1 (one) byte of memory.

g. Unsign int

Uses 2 (two) bytes but cannot be used to store negative numbers and the limit is from 0 to 65.35 .

h. Unsigned Long

i. Double

Double digits with maximum precision 1.797693134823157 x 10

30B 


\section{j. String}

Strings are used to store text information, with ASCII characters and can use strings to send messages via a serial port or display text on a Liquid Crystal Display (LCD) screen.

k. Arrays

Array is a collection of variables of the same type where each variable in the variable set contains elements and data is accessed through an index. Usage example:

Initialize pin 3, pin 5, pin 6, pin 7

Int pints []$=\{3,5,6,7\}$;

\section{Research Methods}

\subsection{Type of Research}

In conducting this research, the type of research used is quantitative research with experimental methods. The experiment is defined as a research situation in which at least one independent variable, which is referred to as the experimental variable, is deliberately manipulated by the researcher (Emzir, 2009). This type of research was chosen because the author developed a tool and conducted research in the form of experiments on the author's research object.

In this study, the author focuses on designing a tracking system for remote controlbased solar power plants to produce more optimal energy values.

\subsection{Block Diagram System}

A Block diagram is the process of the basic circuit system that will be designed and describes, in general, the process of how the circuit works as a whole, and each block has its function.

This block diagram serves so that the author easily analyzes how the circuit works and can design the hardware that will be made. The block diagram of the designed system can be seen in Figures 2.

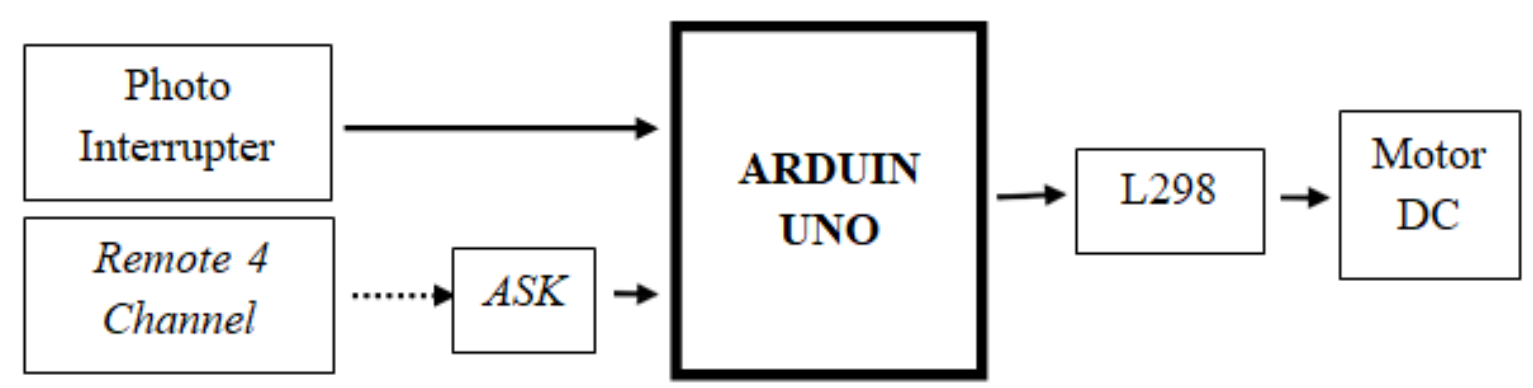

Figure 2. Block Diagram

The functions of each of these block diagrams are:

a. Arduino Uno

The function of the Arduino Uno is as the control center of the entire input and output system.

b. Photo interrupter

The function of the Photo interrupter is as a sensor to limit the movement of the dc motor so that there is no excessive movement of the dc motor which can damage the mechanics of the tool being built. 
c. Remote 4 channel

The function of the 4 channel Remote is to control or move the built device remotely whose distance is limited.

d. $\mathrm{L} 298$

The function of the L298 is to control the movement of the DC motor in driving the solar panels.

e. DC Motor

The function of the DC motor is to drive solar panels to get more optimal sunlight.

\subsection{Data Source}

The source of data in this study is library research which is a way of collecting data from several books, journals, theses, and other literature that can be used as a reference for discussion in this problem. This research is related to online or internet data sources in the form of articles about solar technology or the results of previous research as reference material for authors.

\subsection{Research Procedure}

The steps used in the study are divided into several parts as follows:

a. Literature Study

Collect all references related to Arduino Uno R3, Solar Panel, L298 motor driver, DC Motor, Photo interrupter, Remote control, Switching voltage regulator, actuator, and battery.

b. System Design

For design, the tools used in designing the tracking system for this solar power plant include:

1. 1(one) solar panel

2. 1(one) DC motor

3. 1(one) Motor Driver

4. 2(two) Photo interrupters

5. 1(one) Remote control

6. Actuator and

7. battery

c. Tool Making

In this step, the tool is made based on the previously designed design.

d. Evaluation

After the tool is completed, the next step is to test the tool by applying it to a miniature solar power plant, given a flashlight to determine the voltage that will be received and generated on the battery.

e. Conclusion

Conclusions on the system that has been designed and ready to be used are taken after the trial or discussion process is carried out.

f. Report Writing as a Result of the Final Project 


\section{Results and Discussion}

\subsection{Motor Test}

In testing the DC motor, the author measures the voltage generated by the DC motor in the direction of rotation of the solar panel through a digital voltmeter, using the red test lead (+) connected to the 1298 module and the black test lead (-) connected to the power supply.

To test the DC motor in measuring the voltage through a digital voltmeter, this is done after the author makes a command via the remote control to rotate the solar panel in the desired direction and to direct it the author presses the A button on the remote control, which means the solar panel is ready to be rotated to the left and the left. if you want to turn to the right then you only need to press the $\mathrm{C}$ button on the remote control that has been connected to the tool that has been built. The following results from the measurements of the DC motor are shown in Table 1 and Figures 3.

Table 1. DC motor rotation voltage

\begin{tabular}{|c|c|c|}
\hline $\begin{array}{c}\text { Button } \\
\text { A }\end{array}$ & $\begin{array}{c}\text { Button } \\
\text { C }\end{array}$ & Solar Panel Direction \\
\hline 5.04 volt & 0 volt & Turn left \\
\hline 0 volt & 5.05 volt & Turn right \\
\hline 0 volt & 0 volt & Stop \\
\hline 5.04 volt & 5.04 volt & Stop \\
\hline
\end{tabular}

\subsection{LM2596. Regulator Testing}

In testing the $1 \mathrm{~m} 2596$ module, this is done by measuring the input and output voltages of the $\operatorname{lm} 2596$ module using a digital voltmeter. Measurements made on the $\operatorname{lm} 2596$ module are divided into 2, namely as follows:

\section{a. LM2596. Module Input Measurement}

In testing on the input of the LM2596 module, it aims to find out how much volts is issued at the input of the LM2596 module using a digital voltmeter using the red test lead (+) connected to the Input (+) and the black test lead (-) connected to the input (-) on the LM2596 module. and from the results obtained when testing on the input module, $\operatorname{lm} 2596$ issued a voltage of 12.44 volts. The following results from the LM2596 module input test can be seen in the image below: 


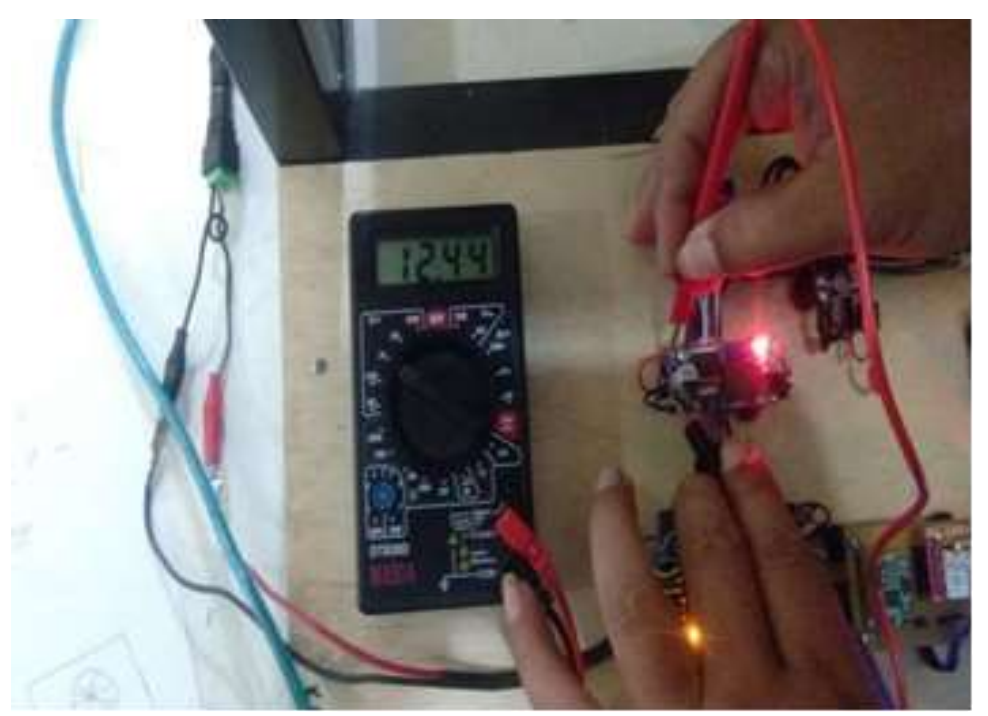

Figure 3. Testing Of Regulator

\section{b. LM2596. Module output measurement}

In modeling testing the output of the LM2596 module, it aims to find out how many volts are issued at the output of the LM2596 module using a digital voltmeter using a red test lead (+) connected to the output (+) and a black test lead (-) connected to the output (-) on the LM2596 module. and from the results obtained when testing on the output of the LM2596 module issued a voltage of 5.08 volts. The following results from testing the output of the LM2596 module can be seen in the image below:

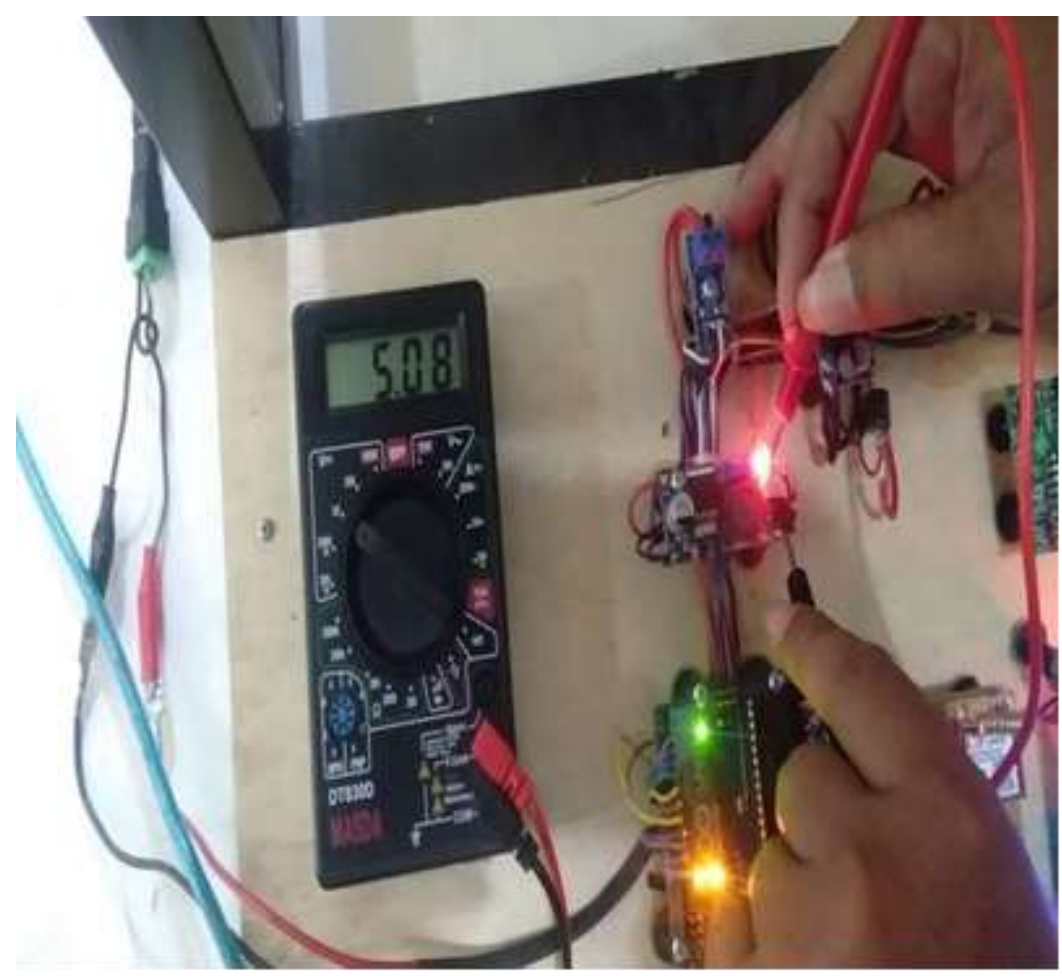

Figure 4. Voltages Modul 


\section{Conclusion}

Based on the results of the research, the conclusions that the author obtained are that the manufacture of this system uses $\mathrm{C}$ language with Arduino Ide software, Remote control as a tool to command the solar panels to move, DC motors as a driver of solar panels and some other supporting hardware. The design of this system requires several stages, namely Block diagrams, making a series of programs, testing programs, and flowcharts. The design of this system is expected to make it easier for solar panel users such as:

1. Control the movement of solar panels based on remote control from a maximum distance of 10 meters from the distance of the solar panels.

2. Make it easier for solar panel users to get the sun's position quickly and precisely.

\section{References}

Arifin W.I, Triyogatama Wahyu W \& Tri Wahyu Supardi (2016), Sistem Kontrol Torsi Pada Motor DC, Jurnal Ilmiah Ilmu Komputer, FMIPA UGM.

Bambang Hari Purwoto (2018), Efisiensi Penggunaan Panel Surya Sebagai Sumber Energi Alternatif, Fakultas Teknik Universitas Muhammaddiyah Surakarta.

Fachri, barany, agus perdana windarto, and ikhsan parinduri. "penerapan backpropagation dan analisis sensitivitas pada prediksi indikator terpenting perusahaan listrik." jepin (jurnal edukasi dan penelitian informatika) 5.2 (2019): 202-208.

Fachri, b., windarto, a. P., \& parinduri, i. (2019). Penerapan backpropagation dan analisis sensitivitas pada prediksi indikator terpenting perusahaan listrik. Jepin (jurnal edukasi dan penelitian informatika), 5(2), 202-208.

Fachri, barany; windarto, agus perdana; parinduri, ikhsan. Penerapan backpropagation dan analisis sensitivitas pada prediksi indikator terpenting perusahaan listrik. Jepin (jurnal edukasi dan penelitian informatika), 2019, 5.2: 202-208.

Fiqih Akbari, Beni Irawan, \& Yulrio Brianorman (2015) Perancangan Aplikasi Remote Control Untuk Perangkat Elektronik Menggunakan HP Berbasis Sistem Operasi Android Via Bloetooth by http:// jurnal.untan.ac.id

Gunawan, G. G., Sulaeman, M. (2020). Determining Factors in the Use of Digital Marketing and Its Effect on Marketing Performance inthe Creative Industriesin Tasikmalaya. Budapest International Research and Critics Institute-Journal (BIRCIJournal), Volume 3, No 3, Page: 2543-2550.

Hamdi, nurul. "model penyiraman otomatis pada tanaman cabe rawit berbasis programmable logic control." jurnal ilmiah core it: community research information technology 7.2 (2019).

Hartanto, D. (2020). Sociology Review of Social Phenomenon, Social Rules and Social Technology. Budapest International Research and Critics Institute-Journal (BIRCIJournal). Volume 3, No 2, Page: 1175-1184.

Khalid Fadhlullah, (2017), Solar Tracking Sistem Berbasis Arduino, Jurnal Ilmiah Universitas Islam Negeri Allaudin Makasar.

Kojooyan Jafari, H. (2008). Design and Implementation of DC motor speed controller using fuzzy-adaptive controllers. WSEAS Transactions on Circuits and Systems.

Nalaprana Nugroho \& Sri Agustina (2015), Analisa Motor DC Sebagai Penggerak Mobil Listrik, Jurnal Ilmiah Jurusan Teknik Elektro, Universitas Sriwijaya. Permana, aminuddin indra. "kombinasi algoritma kriptografi one time pad dengan generate random keys dan vigenere cipher dengan kunci em2b." (2019). 
Putra, randi rian, et al. "decision support system in selecting additional employees using multi-factor evaluation process method." (2019).

Putra, randi rian. "implementasi metode backpropagation jaringan saraf tiruan dalam memprediksi pola pengunjung terhadap transaksi." jurti (jurnal teknologi informasi) 3.1 (2019): 16-20.

Saputra, muhammad juanda, and nurul hamdi. "rancang bangun aplikasi sejarah kebudayaan aceh berbasis android studi kasus dinas kebudayaan dan pariwisata aceh." journal of informatics and computer science 5.2 (2019): 147-157

Sidik, a. P., efendi, s., \& suherman, s. (2019, june). Improving one-time pad algorithm on shamir's three-pass protocol scheme by using rsa and elgamal algorithms. In journal of physics: conference series (vol. 1235, no. 1, p. 012007). Iop publishing.

Sigit Nurharsanto \& Adhy Prayitno, (2017), Sun Tracking Otomatis PLTS, Pekanbaru : Teknik Mesin,Universitas Riau.

Sitepu, n. B., zarlis, m., efendi, s., \& dhany, h. W. (2019, august). Analysis of decision tree and smooth support vector machine methods on data mining. In journal of physics: conference series (vol. 1255, no. 1, p. 012067). Iop publishing.

Tasril, v., wijaya, r. F., \& widya, r. (2019). Aplikasi pintar belajar bimbingan dan konseling untuk siswa sma berbasis macromedia flash. Jurnal informasi komputer logika, 1(3).

Widodo Budiharto \& Gamayel Rizal (2007), 12 Proyek Mikrokontroler Untuk Pemula in Elektronika Dan Pemograman

Yusmartato (2016) Perancangan Alat Pengaturan Kecepatan Motor DC Menggunakan Rangkaian DC Berbasis Komputer, Jurnal Ilmiah Jurusan Elektro Universitas Islam Sumatra Utara. 